\title{
The Growth and Fat Nutrition in Lambs Fed a Diet with Treated (Spray-Dried) Beef-Tallow Supplement
}

\author{
Tsutomu FUJIHARA, Satoshi MAEDA, Toshikazu OGINO, \\ Tohru MATSUI ${ }^{1)}$ and Haruki NARUSE ${ }^{2}$ \\ Faculty of Life and Environmental Science, Shimane University, \\ Matsue-shi 690 \\ "Present address : Faculty of Agriculture, Kyoto University, \\ Sakyo-ku, Kyoto-shi 606 \\ ${ }^{2)}$ Present address : Kyokutoh International Co. Ltd. \\ Minato-ku, Tokyo 105
}

(Received January 24, 1996)

\begin{abstract}
An experiment was carried out to investigate the effect of supplementation of spray -dried beef tallow (BT) on fat nutrition, and to discuss the possibility of improving meat quality by stimulation of fat deposition in the muscles of fattening sheep. There were no clear differ. ences in growth rate between the BT-supplemented group and control group, so the feed efficiency was not improved by addition of BT in the present experiment. Plasma triglyceride (TG) level was relatively steady along with their growth in the control group, but a little high in the BT-supplemented group at an early stage of the experiment. The plasma cholesterol level tended to be higher $(\mathrm{P}<0.05)$ in the BT-supplemented group as compared with that in control at 0 , 1 and 3 months after the initiation of experiment. The moisture content of the carcass decreased $(\mathrm{P}<0.05)$ after feeding $\mathrm{BT}$ diet as compared with that after feeding control diet, and, on the contrary, the contents of crude fat tended to increase in lambs fed the BT diet. As a result, the meat (such as the loin) tended to contain more fat in lambs fed the diet with BT than in control. These findings indicate a possibility that the BT treatment, such as spray-drying as in this study, can be used as an energy source to stimulate fat deposition in the muscles of fattening sheep.

Key words : Beef tallow, Fat nutrition, Fattening sheep

Anim. Sci. Technol. (Jpn.) 67 (10) : 869-877, 1996
\end{abstract}

In recent years, to raise dietary energy density, calcium soap of fatty acids are generating keen interest as a feed-grade fat-supplement for feeding lactating cows $\mathbf{s}^{1,1,6,10 \text { ) }}$
About an animal fat (tallow) as dietary supplement for increasing energy supply to ruminants, very few investigation has been done with any positive results ${ }^{7}$, In . In a previous

加工処理牛脂を添加給与した肥育メンヨウの成辰と脂質栄養について：藤原 勉・前田 諭・荻野寿一・松井

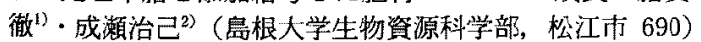

1) 現所属: 京都大学㹃学部, 京都市左京区 606

2) 現所属：キョクトゥインターナショナル株式会社，東京都港区 606

*1) Aii T. Jap. Soc. Anim. Nutr. Meta., 36 : 151. 1992. (in Japanese).

Anim. Sci. Technol. (Jpn.) 67 (10) : 869-877 
FUJIHARA, MAEDA, OGINO, MATSUI and NARUSE

paper $^{3)}$, we suggested that beef-tallow (BT) is useful to improve fat nutrition, when it was supplemented to the diet for sheep as an energy source after treatment, such as spraydrying.

In the present experiment, a fattening trial of lambs was carried out to clarify the effect of supplementation of spray-dried beef tallow (BT) on fat nutrition, and to see if there is the possibility to improve meat quality by stimulation of fat deposition in the muscles of fattening sheep.

\section{Experimental Procedures}

\section{Animals and management}

Four Japanese Corriedale female lambs and 2 wethers, and 2 Suffolk lambs (female and male) were adopted at 5-7 month-old (av. BW : $30.4+$ 6.4). They were raised in a pen with ad libitum feeding of experimental diet (Table 1) for 6 months. In practice, the diet were separately offered to lambs, i.e., two troughs were placed in each pen for roughage and concentrate diet.

\section{Treatments and design}

The lambs used in this study were not always the same in their background before adopted for the experiment, so they were ex. posed to experimental diet for about 4 weeks (-1 month). Then, the sheep were divided into 2 groups ; BT-supplemented group fed the diet ad libitum with BT $(\mathrm{A})^{* 2,3)}$ at $3 \%$ level $^{* \text { (3) }}$ of dry matter of the concentrate diet (two Japanese Corriedale female lambs and one wether, and one Suffolk male lamb), and control group fed ad libitum the experimental diet alone (two Japanese Corriedale female lambs and one wether, and one Suffolk female lamb). However, one of the wether in BT-supplemented group was excluded due to an accident in the $3^{\text {rd }}$ month. During the experimental period, each animal was weighed every month, and the feed intake also checked every month, i.e. daily feed intake per head was calculated from total intake of concentrate feed per week in each group. At the end of the fattening period, two animals in each group were slaughtered and

Table 1. Ingredients and chemical composition of experimental diet

\begin{tabular}{lrc}
\hline \hline \multicolumn{1}{c}{ Concentrate $(60.0 \%)$} & Roughage $(40.0 \%)$ \\
\hline Ingredients & $82.7^{*}(49.5)$ & Sudangrass hay \\
Rolled barley & $16.7 \quad(10.0)$ & $\begin{array}{c}\text { (sorghum sudanense } \\
\text { (Piper) Stapf.) }\end{array}$ \\
Wheat bran & $0.6 \quad(0.5)$ & \\
Calcium carbonate & & 88.7 \\
Chemical composition (\% of DM) & 92.4 & 9.5 \\
Organic matter & 9.6 & 2.0 \\
Crude protein & 3.2 & 47.7 \\
Crude fat & 1.4 & \\
Crude fibre & 78.2 & \\
Nitrogen free extract & 80.0 & \\
\hline Ingredients of spray-dried beef tallow $(\%, \mathrm{w} / \mathrm{w})^{* * *}$ & \\
Beef tallow & 17.5 & \\
Whey powder & 2.5 & \\
Casein & & \\
\hline
\end{tabular}

*\% of total concentrate feed.

** see Fujihara et al. (1996).

*2) Spray-dried BT coated with casein $(2.5 \%, \mathrm{~W} / \mathrm{W})$ and whey powder $(17.5 \%, \mathrm{~W} / \mathrm{W})$.

* a) Average BT consumption calculated as $16.4-26.4 \mathrm{~g} / \mathrm{head} /$ day (based on the figures indicated in Tables 1 and 2) 
the meat quality was checked.

\section{Sample collection}

About $10 \mathrm{~m} l$ of jugular blood was sampled at $17: 00 \mathrm{hr}$ from each animal every month to measure the components of plasma lipid; The first sampling of blood ( -1 month) was done at 2 weeks before grouping, and 2 weeks later, the $2^{\text {nd }}$ sample was taken $(0$ month $)$, then, $3^{\text {rd }}$ to $7^{\text {th }}$ samples of blood were monthly collected after $2^{\text {nd }}$ sampling. Therefore, The figures indicating lipid metabolites in plasma at 0 month have shown the values at 2 weeks after the initiation of experiment.

To check the meat quality and the lipid contents of meat, samples of meat were taken from. the loin, fillet and round of the carcass.

\section{Analytical methods}

Feed: The nitrogen, crude fat, crude fibre and crude ash contents in the diet were determined according to $\triangle O A C$ method ${ }^{4)}$.

Blood Plasma: The triglyceride (TG) and cholesterol in blood plasma were determmined by the acetyl-acetone method ${ }^{2)}$ and cholesterol oxidase phenol method ${ }^{9)}$, respectively, using the commercial test-reagents (Wako Chemical Co. Ltd. Osaka, Japan).

Carcass sample: Meat color was measured by the color meter (Model KC-300, Karusonyu Optics Industry), which checks the values; $L$ : brightness, a : grade of redness, b: grade of yellowness. The moisture, crude protein and crude fat contents of minced flesh (muscle) were measured according to $\mathrm{AOAC}^{11)}$. The fatty acids compositions in the meat and adipose tissue (subcutaneous fat) was measured by gas chromatography after the separation of triglyceride fraction by thin-layer chromatography ${ }^{5}$.

Test of significance between the two groups was done by the $t$-test.

\section{Results and Discussion}

Growth and fattening: In the present study, the breed and sex of lambs used were not always similar in both groups, and there were also little differences (1-2 months) in the age at which they were adopted for the experiment. It may therefore not be appropriate to directly
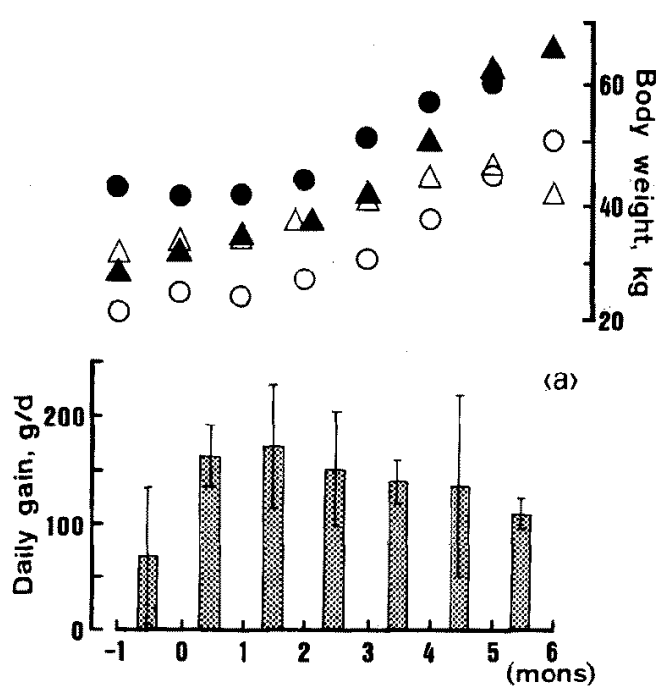

Months of fattening
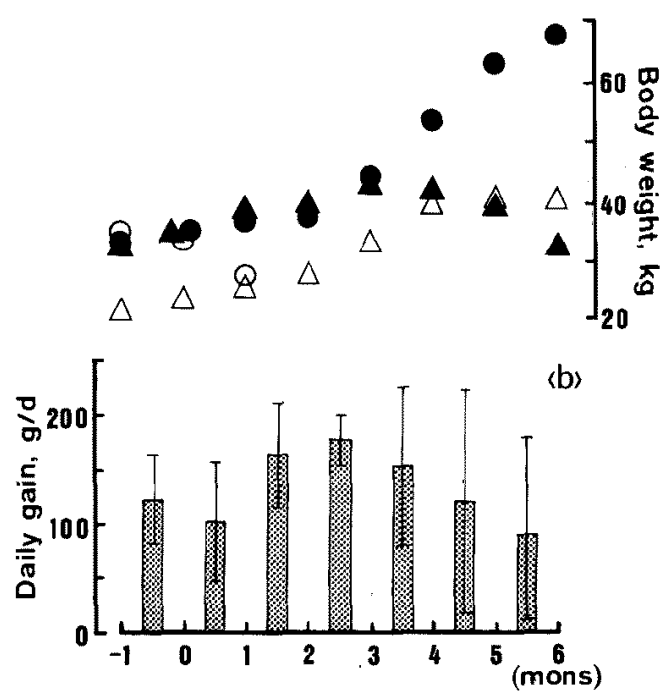

Months of fattening

Fig. 1. The growth curves and daily gain of lambs during fattening. (a): Control group. (b) : BT-supplemented group.

- Lamb No. 1, $\mathrm{O}=$ Lamb No. 2, $\boldsymbol{\Delta}=$ Lamb No. 3, $\triangle=$ Lamb No. 4 . 
compare their growth rate after initiation of the experiment. The growth rate are therefore shown individually, and daily gain (DG) as an averaged value in each group (Fig. 1). DG of the control group increased till 2 months after initiation of experiment (maximum value $: 172.4 \pm 56.9 \mathrm{~g} / \mathrm{d}$ ), and then decreased gradually. The DG in BT- supplemented group increased till 3 months after the initiation (maximum value : $177.4 \pm 22.6 \mathrm{~g} / \mathrm{d}$ ), and then decreased gradually.

In this study, the diets (hay and concentrate) were offered separately, and daily intake of hay was relatively constant $(200-300 \mathrm{~g} /$ head), although daily intake of concentrate fairly

Table 2. Feed (concentrate) intake of lambs during the experimental period $(\mathrm{g} / \mathrm{head} / \mathrm{d})$

\begin{tabular}{ccc}
\hline \hline & Control & BT $^{*}$ diet \\
\hline$-1^{* *}$ & $690.1 \pm 126.7^{* * *}$ & $686.7 \pm 118.3$ \\
0 & $710.2 \pm 133.4$ & $741.5 \pm 126.9$ \\
1 & $762.1 \pm 128.2$ & $775.5 \pm 111.8$ \\
2 & $868.2 \pm 156.3$ & $880.6 \pm 107.9$ \\
3 & $967.8 \pm 170.4$ & $956.1 \pm 110.0$ \\
4 & $990.1 \pm 156.9$ & $987.2 \pm 136.3$ \\
5 & $1,104.6 \pm 177.2$ & $1.043 .4 \pm 245.0$ \\
\hline
\end{tabular}

* Spray dried beef tallow.

** Month after the initiation of experiment.

*** Mean士S.D. of $3 \sim 4$ sheep. varied during the experiment. As shown in Table 2, however, there were no statistical differences in intake of concentrate diet of both groups during fattening. As a result, there were no clear differences in growth rate of the two groups, so the feed efficiency was not improved by the addition of BT. In the BTsupplemented group, two lambs apparently lost their appetite at 3-4 months after initiation of the experiment and, consequently, their DG did not increase until the end of experiment. This may be due to some disorder (adiposis) caused by over intake of fat, though not confirmed in this study. Furthermore, the supplemented level of BT might be thought to be a little high for some individuals, because the lambs were group fed throughout the experiment in both groups, and the level of BT intake was not checked individually in the BTsupplemented group. In any case, the marked decrease of DG at 3-4 months after initiation in the case of the 2 lambs in the BT-supplemented group would be obviously caused by a decrease in food intake, although the reason for the abrupt reduction of food intake could not be explained.

Fat nutrition during fattening: The plasma concentration of $\mathrm{TG}$ varied with their growth in control group, but relatively high in BT-

Table 3. The monthly changes in concentrations of triglyceride and cholesterol in blood plasma of sheep during fattening

\begin{tabular}{cccccc}
\hline \hline & \multicolumn{2}{c}{ Triglyceride $(\mathrm{mg} / \mathrm{d} l)$} & & \multicolumn{2}{c}{ Cholesterol $(\mathrm{mg} / \mathrm{d} l)$} \\
\cline { 2 - 3 } \cline { 5 - 6 } & Control & $\mathrm{BT}^{*}$ diet & & Control & BT diet \\
\cline { 5 - 6 } \cline { 5 - 6 } $\mathbf{1}^{* *}$ & $48.4 \pm 6.7^{* * *}$ & $77.9 \pm 23.8$ & & $42.0 \pm 28.9$ & $41.4 \pm 4.5$ \\
0 & $67.6 \pm 21.0^{\mathrm{a}}$ & $133.3 \pm 23.8^{\mathrm{b}}$ & & $49.1 \pm 9.8^{\mathrm{a}}$ & $91.0 \pm 6.6^{\mathrm{b}}$ \\
1 & $34.2 \pm 7.5^{\mathrm{a}}$ & $59.4 \pm 10.7^{\mathrm{b}}$ & & $48.6 \pm 21.5^{\mathrm{a}}$ & $88.6 \pm 18.5^{\mathrm{b}}$ \\
2 & $48.9 \pm 6.4^{\mathrm{a}}$ & $75.1 \pm 16.2^{\mathrm{b}}$ & & $71.7 \pm 6.2$ & $103.2 \pm 30.9$ \\
3 & $59.4 \pm 14.8$ & $58.7 \pm 15.8$ & & $86.2 \pm 24.8^{\mathrm{a}}$ & $101.7 \pm 29.1^{\mathrm{b}}$ \\
4 & $44.0 \pm 6.1$ & $54.0 \pm 15.8$ & & $77.0 \pm 11.3$ & $106.8 \pm 38.7$ \\
5 & $70.8 \pm 11.4$ & $73.2 \pm 43.2$ & & $78.8 \pm 10.5$ & $191.4 \pm 50.2$ \\
\hline
\end{tabular}

* Spray dried beef tallow.

** Month after the initiation of fattening.

*** Mean \pm S.D. of 3-4 sheep.

${ }^{a-b}$ Values with different superscript letters were significantly different $(\mathrm{P}<0.05)$. 
supplemented group at an early stage of the experiment (Table 3). It seemed that the plasma TG level of lambs in BT-supplemented group was originally high as compared with that in control group, i.e., the average value at 1 month before the initiation of experiment was relatively higher in BT-supplemented group than in control group, but not significantly. Therefore, the changes in plasma TG level during fattening is individually shown in Fig. 2 within both groups. With the BT-supplemented group, the plasma TG level of one lamb (No. 3) was markedly high before the initiation of experiment, so it obviously enhanced the average value at 1 month

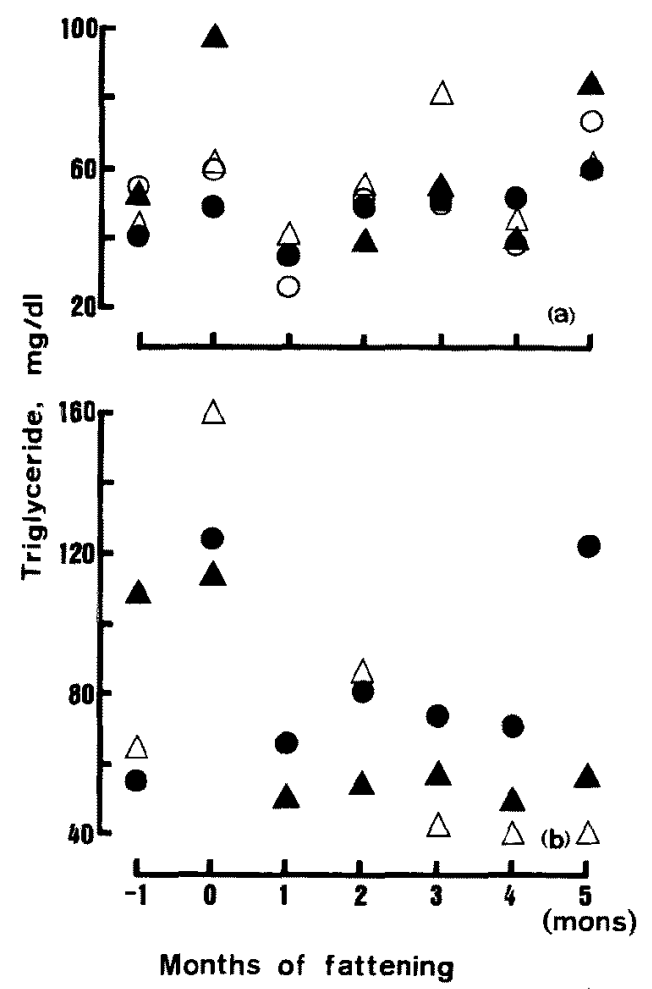

Fig. 2. The time course changes in concentration of plasma triglyceride in sheep during fattening. (a) : Control group. (b) : BT-supplemented group.

- Lamb No. 1, $\bigcirc=$ Lamb No. 2, $\boldsymbol{\Delta}=$ Lamb No. 3 , $\triangle=$ Lamb No. 4 . before the initiation. Plasma TG level of the No. 3 lamb was slightly elevated just after the initiation of experiment, and then, markedly decreased compared to those of the two other lambs before the initiation of experiment during 1-4 months. On the other hand, plasma TG levels of the other two lambs (Nos. 1 and 4) in the same group also increased remarkably just after feeding the BT diet (at 0 month), and then, decreased to a quite low level (a little higher than that in control group) during 1-4 months. On the final month (just before slaughtering), the plasma TG level of the No. 1 lamb abruptly increased again to the level just after feeding the BT diet (at 0 month). In the control group, contrarily, the plasma TG levels of the three lambs did not significantly change after the initiation of experiment, although a slight increase was observed just after the initiation and on the final month. The BT used in this study was mostly composed of TG which could be absorbed easily, therefore, the increment in plasma TG level just after feeding the diet with BT could be due to an increase of TG derived directly from digestion of supplemented BT. Then, as a result, the average plasma TG level within 0-2 months after the initiation of experiment was higher $(\mathrm{P}<0.05)$ in the BT-supplemented group than in control group, although a direct comparison of the plasma TG level in the two groups will be not always be accurate in this study because of the reason mentioned above.

In the time course changes in plasma level of TG during fattening of cattle, it has been demonstrated that plasma TG level seems to be relatively steady at the early stage ${ }^{* 4)}$. This would be due to the fact that during the early stage of fattening, the absorbed TG is positively incorporated into the hypodermic area or the surrounding area of internal organs where fat is relatively accumulated easily, so the plasma TG level can be used intensively for fat deposition in the body ${ }^{8)}$. As fattening pro-

\footnotetext{
${ }^{*}$ 4) Hidaka S, Hidari H. Jap. Soc. Anim. Nutr. Meta., 35 : 133. 1991. (in Japanese)
} 
gresses, in particular at the late stage, the adipose tissues under the skin or the surrounding of the internal organs can no longer incorporate more TG, and therefore, the supply of fatty acids in the body is more than what the adipose tissue could hold. Consequently, the TG level in the circulating blood would be high at that time. On the other hand, an increase in TG in circulating blood could be thought to be possibly accelerating fat deposition within and/or between muscles where fat will be hard to store up generally. From these findings, in sheep fed BT diet in this study, it could be presumed that the remarkable increase of $\mathrm{TG}$ in plasma just after the initiation of BT supplementation (early stage during fattening period) could have promoted fat deposition in

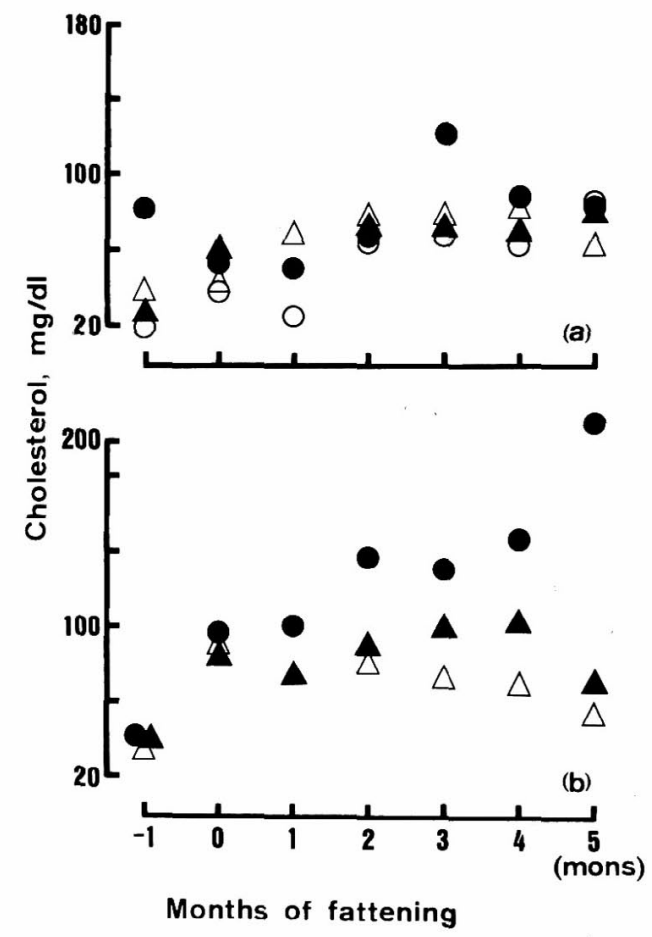

Fig. 3. The time course changes in concentration of plasma total cholesterol in sheep during fattening. (a) : Control group. (b) : BTsupplemented group.

$\mathbf{0}=$ Lamb No. 1, $\mathrm{O}=$ Lamb No. 2, $\boldsymbol{\Delta}=$ Lamb No. 3, $\triangle=$ Lamb No. 4 . the muscles from early stage during fattening period, and these conditions obviously differed from that observed generally in the adipose tissues of beef cattle during fattening. Consequently, a lot of fat was thought be accumulated in the muscles as shown in Fig. 4.

The plasma cholesterol level was relatively higher $(\mathrm{P}<0.05)$ in the BT-supplemented group as compared with that in control group at 0,1 and 3 months after the initiation of experiment. Although the plasma level of cholesterol was similar in both groups before the initiation of experiment, the plasma TG level was quite different in both groups at the same stage. As shown in Table 3 and Fig. 3, the cholesterol in plasma also gradually increased as fattening progressed in both groups, and this increase of plasma cholesterol was thought to result in an increase in TG absorbed, because it is well known that TG is closely related to cholesterol synthesis in the liver ${ }^{3)}$. Cholesterol is also thought to act as a carrier which transports esterified fatty acids (cholesterol ester) in the circulating blood. Therefore, in the present experiment a possibility was suggested that the high cholesterol level in the blood plasma
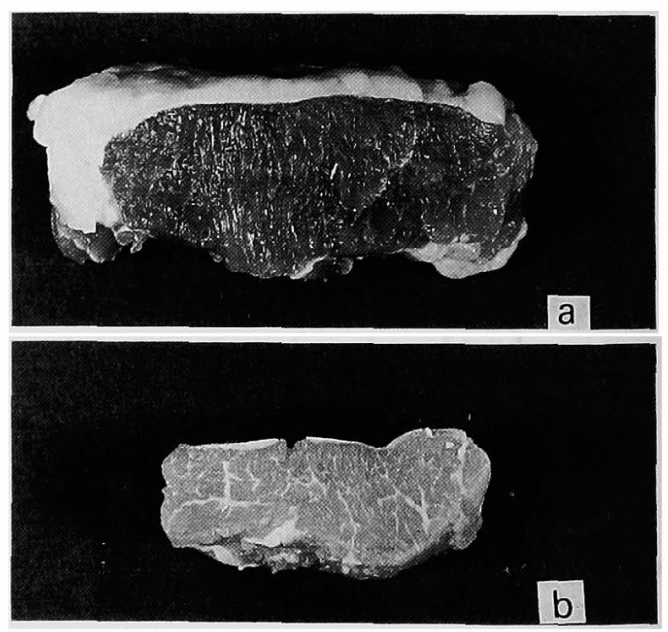

Fig. 4. (A) The cross section of loin meat in lambs fattened with control diet (a: lamb No. 2) and BT-diet (b : lamb No. 3). 
after feeding the diet with BT could strengthen fat deposition through increased transport of fatty acids.

Carcass quality: In the present study, the
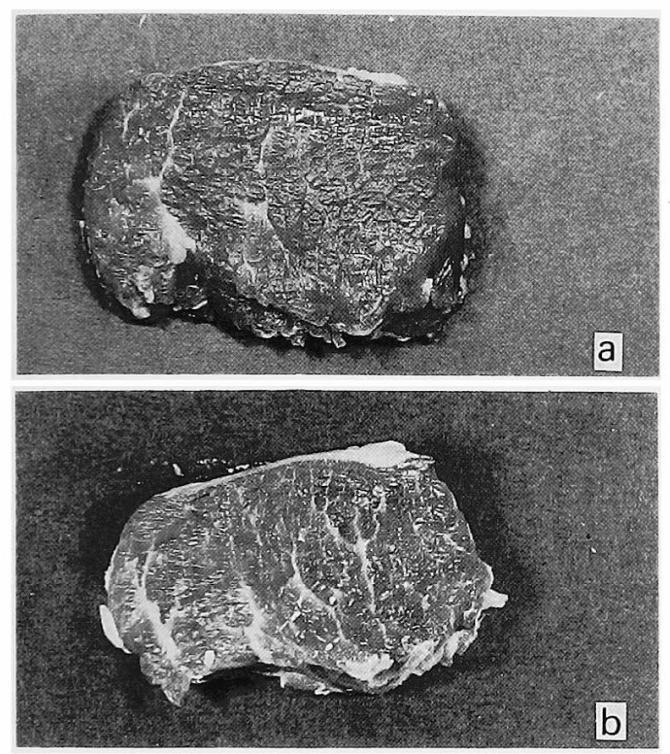

Fig. 4. (B) The cross section of loin meat in lambs fattened with control diet (a: lamb No. 3) and BT diet (b : lamb No. 1). thickness of subcutaneous fat (such as back fat) was not checked in detail after slaughtering, and a grade of marbling in the loin meat was not distinguished as beef quality. The marbling condition was only observed with the naked eye as shown in the Fig. $4 \mathrm{~A}$, B. The moisture contents of the loin and round was lesser $(\mathrm{P}<0.05)$ in the BT supplemented group than in the control group. The contents of crude protein of the round was also lower $(\mathrm{P}<$ 0.05 ) in the BT-supplemented group than in control group. The content of crude fat of the round meat was higher $(\mathrm{P}<0.05)$ in the $\mathrm{BT}$ supplemented group than in control group, and that of the loin and fillet were also fairly greater, but not significantly, in the former than in the latter (Table 4). Regarding the composition of fatty acids, there was no clear difference in the contents of saturated fatty acid in flesh (muscle) and adipose tissue (subcutaneous fat) in the BT-supplemented group as compared with the control group (Table 5). As described above, the plasma TG level was a little higher in the BT-supplemented group as compared to control group (see Table 3 and Fig. 2), however, the composition of fatty acids within the flesh

Table 4. The moisture, crude protein and crude fat contents in the muscles, and the meat colour after fattening

\begin{tabular}{|c|c|c|c|c|c|c|}
\hline & & \multicolumn{2}{|c|}{ Composition of muscle } & & \multicolumn{2}{|c|}{ Meat colour } \\
\hline & & Control & $\mathrm{BT}^{*}$ diet & & Control & BT diet \\
\hline \multirow[t]{3}{*}{ Loin } & Moisture & $70.6 \pm 1.2^{\mathrm{a} * *}$ & $64.9 \pm 0.6^{b}$ & Brightness & $29.0 \pm 0.1$ & $30.3 \pm 3.2$ \\
\hline & Crude protein & $67.2 \pm 5.6$ & $52.2 \pm 4.2$ & Redness & 4. $3 \pm 0.1$ & $7.6 \pm 1.5$ \\
\hline & Crude fat & $21.3 \pm 3.8$ & 39. $8 \pm 6.2$ & Yellowness & $2.2 \pm 0.1^{\mathrm{a}}$ & $3.7 \pm 0.3^{b}$ \\
\hline \multirow[t]{3}{*}{ Fillet } & Moisture & $71.2 \pm 1.2$ & $68.2 \pm 1.3$ & Brightness & $30.4 \pm 1.6$ & $31.2 \pm 1.6$ \\
\hline & Crude protein & $65.6 \pm 7.3$ & $57.6 \pm 1.2$ & Redness & $6.6 \pm 0.1$ & $7.8 \pm 2.6$ \\
\hline & Crude fat & $26.6 \pm 13.8$ & $31.6 \pm 9.4$ & Yellowness & $3.7 \pm 0.6$ & 3. $9 \pm 2.1$ \\
\hline \multirow[t]{3}{*}{ Round } & Moisture & $73.5 \pm 0.7^{\mathrm{a}}$ & $66.4 \pm 0.6^{b}$ & Brightness & $28.6 \pm 0.1$ & $32.4 \pm 3.4$ \\
\hline & Crude protein & $71.4 \pm 2.1^{\mathrm{a}}$ & 53. $7 \pm 3.5^{\mathrm{b}}$ & Redness & 7. $1 \pm 0.4$ & $8.1 \pm 0.6$ \\
\hline & Crude fat & $13.7 \pm 0.2^{\mathrm{a}}$ & $46.8 \pm 9.2^{b}$ & Yellowness & $3.2 \pm 0.4$ & $3.6 \pm 0.4$ \\
\hline
\end{tabular}

\footnotetext{
* Spray dried beef tallow.

*** Mean \pm S.D. 2 sheep in each group.

${ }^{\mathrm{a}-\mathrm{b}}$ Values with different superscript letters were significantly different $(\mathrm{P}<0.05)$.

The contrasts of crude protein and crude fat are shown as \% of dry matter.
} 
FUJIHARA, MAEDA, OGINO, MATSUI and NARUSE

Table 5. The fatty acid composition of fat in the muscle and subcutaneous fat of fattening sheep $(\%)$

\begin{tabular}{llll}
\hline & & Control & BT*-diet \\
\hline Muscle** $^{* *}$ & Saturated & $46.9 \pm 1.2^{* * *}$ & $48.3 \pm 1.6$ \\
& Unsaturated & $53.1 \pm 1.3$ & $51.7 \pm 1.5$ \\
Subcutaneous fat & Saturated & $51.5 \pm 2.1$ & $52.0 \pm 1.5$ \\
& Unsaturated & $48.5 \pm 2.0$ & $48.0 \pm 1.7$ \\
\hline
\end{tabular}

* Spray dried beef tallow.

** Loin.

${ }^{* * *}$ Mean \pm S.D. of 2 sheep.

and adipose tissue did not change with feeding of BT diet. The reason why there was no clear relationship between the plasma TG level and the composition of fatty acids in the fat within flesh and/or adipose tissue could not be clarified in this experiment.

The meat color or brightness was measured by the color meter. In general, the cut face of lean meat will show a red color, and the fat deposited (within meat and in adipose tissues) will show a yellow (or white), and then, a cut surface of well marbled meat will be more yellowish than that of poor marbled one. In the color of flesh, which was measured as an indicator for checking the extent of marbling (or ratio of fat and lean on surface of cut flesh), the yellowness of loin meat was stronger $(\mathrm{P}<0.05)$ in BT-supplemented group than in control group (Table 4). The brightness, redness and yellowness in all the samples was relatively stronger in the BT supplemented group than in control group, except the yellowness of loin, but not significantly.

It is generally well known that the fat contents in the muscles tend to increasc, and on the contrary, moisture content in the muscles tend to decrease with time during fattening*5). Therefore, the deposition of fat within muscles was accelerated through the feeding of BT diet in BT-supplemented group, while moisture in muscles was thought to be lowered relatively after feeding the BT diet in this study.
In the present study, the contents of saturated fatty acids in muscles and the subcutaneous fat was a little higher in the BT supplemented group than that in the control group. In general, it is well known that beef tallow contains more saturated fatty acids than other fats. It could therefore be supposed that the high content of saturated fatty acids in the adipose tissues of sheep fed BT diet was presumably due to the high level of saturated fatty acids of supplemented BT (Table 5).

The loin meat contained slightly more fat in BT-supplemented lambs than in control, a marbling condition observed with the naked eye (Fig. $4 \mathrm{~A}, 4 \mathrm{~B}$ ). In Japan a well marbled becf attracts attention ${ }^{13)}$ and marbling is a very important factor to produce a high quality beef. Other criteria for describing beef quality other than marbling are as follows ; meat color, firmness, quality of fat, tenderness, an extent of succulence and flavor. It is thought that firmness of meat is produced by decreasing moisture content in the muscle, and on the other hand, tenderness of meat is obviously stimulated by marbling ${ }^{(3)}$. Further, body fat generally contains a lot of saturated fatty acids, and therefore becomes relatively hard and whitened. In the present experiment, meat containing low moisture, more fat and also well marbled was produced, and fat within the muscle containing a little more saturated fatty acids was produced by supplementation

*5) Palmquist DL. Feeding., 27 (No. 3) : 47. 1987. (in Japanese. translated by N. Hayami). 


\section{Utilization of beef-tallow in sheep}

of BT in the diet. From these results, the possibility of improving meat quality was suggested when spray-dried beef tallow was used for fattening sheep.

\section{Acknowledgements}

The authors gratefully acknowledge the kind assistance of Mr. M. Okabayashi during the course of experiment.

\section{References}

1) Eastridge ML. Palmquist DL. Supplemental energy as calcium soap beginning at two or six weeks of lactation. J. Dairy Sci., $71: 254$. (Suupl.1). 1988.

2) Fletcher MJ. A colorimetric method for estimating serum triglycerides. Clin. Chim. Acta., 22 : 393-397. 1968.

3) Fujihara T, Maeda S, Matsui $T$, Naruse $H$. The effect of treated (Spray-dried) beef-tallow supplementation on feed digestion, ruminal fermentation and fat nutrition in sheep. Anim. Sci. Technol.(Jpn.), 67 : 14-23. 1996.

4) Hoitz H. (ed.) Official Methods of Analysis. $9^{\text {th }}$ ed. A.O.A.C. 283-288. Washington D.C. 1960.

5) Hwang SG, Torii S, liyas A, Matsui $T$, Yano $H$. Comparative changes of fat digestibility and fat accumulation by the carbon chain length of dietary glycerol tri-homogenous fatty acids in rats. Nutr. Res., $14: 1821-1830.1994$.
6) Klusmyer TH, Lynch GL, Clark JH, Nelson DR. Effects of amount of forages and calcium salts of nutrients to small intestines of lactating dairy cows. J. Dairy Sci., $72: 482$ (Suppl. 1). 1989.

7) Kronfeld DS, Donog hue S, Naylor JM, Johnson K, Bardley CA. Metabolic effects of feeding protected tallow to dairy cows. J. Dairy Sci., $63: 545-552.1980$.

8) Ozutsumi H. Studies on the estimation of beef quality. Nippon Shokuhin Kohgyo Gakkaishi, $36: 857-866$. 1989. (in Japanese).

9) Richmond W. Preparation and properties of a cholesterol oxidase from Nocardia sp. And its application to the enzymatic assay of total cholesterol in serum. Clin. Chem., 19:13501356. 1973.

10) Schauff DJ, Clark JH. Feeding increasing dietary concentrations of calcium salts of long chain fatty acids (Ca-LCF) to Holstein cows. J. Dairy Sci., $73: 242$ (Suppl. 1). 1990.

11) Williams S. (ed.) Official Methods of Analysis. $14^{\text {th }}$ ed. A.O.A.C. 431-432. Arlington. Virginia USA. 1984.

12) Yang YT, Baldwin RL, Russell J. Effect of long term lipid supplementation on the performance of lactating dairy cows. J. Dairy Sci., 61 : 180-188. 1978.

13) Zenbayashi M. Beef Production (Gyuunikuseisan-no-kagaku). Yokendo Co., Tokyo. 1994. (in Japanese). 